\title{
ДЕРЖАВНА ПОЛІТИКА У СФЕРІ СТРАХУВАННЯ: АДМІНІСТРАТИВНО-ПРАВОВИЙ ВИМІР
}

\author{
ЛЕДВІЙ Олена Іванівна - асистент кафедри адміністративного та \\ інформаційного права Навчально-науковий Інститут права, психології та \\ інноваційної освіти Національного університету «Львівська політехніка». \\ УДК 342.15.134 \\ https://orcid.org/0000-0003-0137-1084 \\ DOI 10.32782/LAW.UA.2020.3.13
}

Статья посвящена исследованию административно-правовых механизмов реализации государственной политики в сфере страхования. Вияснено сущность страховой деятельности и особенности ее осуществления. Проведен анализ соотношения страховой и банковской деятельности. Подчеркнуто, что страховая деятельность, являясь одним из видов предпринимательства, является общественньм процессом, охватвивается государственньлм регулированием в силу своей социальной значимости. При этом цель государственного регулирования страховой деятельности заключается в составлении этого вида предпринимательства, обеспечения стабильности рьлнка страховых услуг и защитъг интересов потребителей этого вида услуг. Регулирование страховой деятельности со сторонъ государства осуществляется в публичнъгх интересах и направлено на достижение сощиально полезньх результатов, стимулирующих прогрессивное развитие страхования в стране.

Государственное регулирование общественнъих отношений должно строиться с учетом интересов и всего общества (т.е. публичных интересов), и частньх интересов отдельныхх индивидов. Прежде всего, это касается экономических отношений, чель государственного регулирования которьих - удовлетворение государственнъхх (публичных) интересов по обеспечению экономического развития государства и защита законньх экономических прав и интересов частньих лии.

Ключевъе слова: страховая деятельность, банковская деятельность, гарантирования вкладов бизических лии, административноправовое регулирование, административно-правовъие механизмъи, административно-правовой режим, государственная политика.

\section{Постановка проблеми}

Страхова діяльність становить професійну комерційну діяльність щодо формування, розподілу та використання коштів страхових фондів з метою захисту майнових інте-ресів фізичних і юридичних осіб при настанні страхових випадків. Здійснюють цю діяльність спеціалізовані комерційні юридичні особи (діяльність страхових посередників агентів, брокерів та інших фахівців на страховому ринку має допоміжний характер, тому до страхової діяльності не відноситься). Ця діяльність підлягає правовому регулюванню, як і будь-яка інша підприємницька діяльність, при цьому правова природа такого регулювання в більшості випадків адміністративна.

Метою цієї статті $є$ розгляд особливостей адміністративно-правових механізмів реалізації державної політики у сфері страхування.

\section{Стан дослідження проблеми}

Деякі аспекти окресленої проблематики були предметом дослідження таких учених, як: В. Авер'янов, В. Білоус, А. Берлач, М. Бліхар, Н. Бортник, С. Єсімов, I. Аиченко, В. Колпаков, О. Остапенко, С. Пєтков, А. Сопільник, В. Шамрай, Х. Ярмакі та ін. 


\section{Адміністративне право}

\section{Виклад основного матеріалу}

Страхова діяльність, будучи одним з видів підприємництва, є суспільним процесом, що охоплюється державним регулюванням у силу своєї соціальної значимості. При цьому мета державного регулювання страхової діяльності полягає в упорядкуванні цього виду підприємництва, забезпечення стабільності ринку страхових послуг і захисту інтересів споживачів цього виду послуг. Регулювання страхової діяльності з боку держави здійснюється в публічних інтересах і спрямовано на досягнення соціально корисних результатів, що стимулюють прогресивний розвиток страхування в державі.

Державне регулювання суспільних відносин має будуватися з урахуванням інтересів і всього суспільства (тобто публічних інтересів), і приватних інтересів окремих індивідів. Насамперед, це стосується економічних відносин, мета державного регулювання яких - задоволення державних (публічних) інтересів щодо забезпечення економічного розвитку держави та захист законних економічних прав та інтересів приватних осіб.

Адміністративно-правове регулювання становить механізм імперативно-нормативного упорядкування організації та діяльності суб'єктів та об'єктів управління і формування стійкого правового порядку їх функціонування. Традиційно одним з елементів адміністративно-правового впливу розглядається державне регулювання.

Структуру державного управління страховим сектором економіки можна розглядати у двох аспектах:

1. Управління страхуванням за допомогою функціонування системи державного страхування, іншими словами, як частиною державного господарства.

2. Управління страхуванням як сектором економіки, за допомогою нормативного регулювання страхової діяльності.

Перший з названих аспектів - державне страхування - 6 на сучасному етапі абсолютно особливим механізмом реалізації державної політики, що має адміністративно-правовий характер.

Відповідно до чинного законодавства відрахування в страхові державні фонди (пенсійний, медичного та соціального страхуван- ня) отримали статус податкових платежів, 3 витікаючими з цього статусу контрольними повноваженнями компетентних органів і відповідальністю за несплату таких платежів. Державні страхові фонди є самостійною ланкою фінансової системи держави, самостійним об'єктом правового регулювання і включаються в державний сектор економіки.

На думку деяких вчених, правовідносини у сфері державної власності (в тому числі в рамках державних страхових фондів) відносяться, передусім, до сфери цивільно-правового регулювання.

Держава у цьому випадку є власником, яка реалізує свої речові права щодо належного їй майна - страхового фонду грошових коштів, а отже, правовідносини, що виникають у процесі такої діяльності є за своєю суттю господарськими і повинні регулюватися цивільним правом [1].

Такий підхід видається не зовсім обгрунтованим, оскільки не враховує особливостей державної власності (зокрема, публічних цілей ії використання), а також той факт, що процес реалізації державою своїх повноважень у сфері державного господарства виходить за рамки традиційних цивільних правовідносин і є державним управлінням певним сектором економіки.

Державне страхування становить частину державної власності, орієнтованої на задоволення саме публічних інтересів усього суспільства, у той час як інші об’єкти власності використовуються у приватних інтересах. Можна стверджувати, що для суспільних відносин, які виникають у сфері державного страхування, характерні, передусім, такі особливості: вони спрямовані на досягнення публічних інтересів і за своєю суттю $є$ управлінськими, тобто виникають у сфері державного управління.

Низка вчених також підкреслює, що державну власність необхідно розглядати не тільки в цивільно-правовому сенсі. Під державною власністю можуть розумітися різноманітні відносини, побудовані за ієрархічним принципом:

- всередині органів законодавчої та виконавчої влади, які пов'язані з володінням, користуванням і розпорядженням державним майном, затвердженням бюджету; 
- між центральними і регіональними органами державної влади та місцевого самоврядування;

- між апаратом держави і державними підприємствами як реальними товаровиробниками [2, с. 271-278].

Як зазначає Е.В. Талапіна, відносно державної власності акцентується не власницький, цивілістичний аспект, а управлінський $[3$, с. 72].

Отже, тут доречно говорити про адміністративно-господарські правовідносини, що виникають у процесі управління державним страхуванням. У процесі державного управління державними страховими фондами складаються організаційні адміністративно-господарські відносини, тобто такі, що стосуються питань забезпечення функціонування страхових фондів (щодо структури фондів, визначення цілей їх діяльності, реорганізації та ліквідації фондів, визначення ïx правосуб'єктності шляхом закріплення іiі в статутних документах, ліцензування діяльності, призначення (відсторонення) керівництва фондів, контроль за діяльністю фондів у частині дотримання ними вимог чинного законодавства України).

Другий із названих аспектів - нормативне регулювання страхової діяльності - також має свої особливості. Таке регулювання за своєю природою є адміністративно-правовим.

Адміністративно-правове регулювання страхової діяльності не охоплює весь пласт страхових відносин, більш значна їх частина регулюється приватним правом, тобто об'єктом цього виду правового регулювання є умови ведення страхової діяльності.

Держава регулює страхову діяльність за допомогою:

- встановлення умов допуску на страховий ринок організацій, які збираються надавати послуги зі страхування (отримання ліцензії);

- визначення фінансових нормативів для страховиків;

- закріплення принципів інвестування коштів страхових фондів;

- здійснення адміністративного нагляду за діяльністю страховиків;

- встановлення відповідальності за порушення законодавства про страхову діяльність.
Перераховані інструменти становлять зміст адміністративно-правового регулювання страхової діяльності.

За допомогою прийняття правових норм держава отримує можливість стимулювати або обмежувати ринок страхових послуг, забезпечувати його фінансову стабільність та ефективність. Можна виділити такі інструменти державного впливу на страхову діяльність:

1. Встановлення державної процедури легалізації осіб, які бажають професійно займатися страхуванням, тобто процедур державної реєстрації та отримання ліцензії на заняття страховою діяльністю.

2. Встановлення вимог до фінансової стійкості страховиків, тобто нормативне закріплення фінансових показників і принципів інвестиційної діяльності страховиків.

3. Введення процедури адміністративного нагляду за діяльністю страховиків за допомогою створення виконавчого органу спеціальної компетенції.

4. Встановлення адміністративної відповідальності за порушення страхового законодавства.

5. Введення системи обов'язкового страхування.

Умови формування і використання конкретних приватних страхових фондів не підлягають імперативному правовому регулюванню, держава лише встановлює найбільш загальні вимоги, на зразок істотних умов договору страхування, добровільності страхування, цільового характеру використання коштів страхових фондів на виплату страхових відшкодувань. Розміри ж страхових премій (внесків), умови та порядок виплати страхового відшкодування, відповідальність сторін врегульовані двостороннім договором між страховиком і страхувальником.

Звертає на себе увагу той факт, що адміністративно-правове регулювання різних інститутів фінансової системи є нерівномірним. Очевидна зацікавленість держави в стабільному функціонуванні фінансової системи країни, у зв'язку з чим держава висуває певні вимоги до різних типів фінансових організацій. Однак єдності таких вимог не спостерігається.

Порівняємо, наприклад, адміністративно-правові режими страхової та банківської діяльності. 


\section{Адміністративне право}

У банківській системі спостерігається жорстке регулювання фінансової стійкості. Так, з метою забезпечення фінансової надійності «банки зобов'язані формувати резервний фонд на покриття непередбачених збитків по всіх статтях активів та позабалансових зобов'язаннях.

Розмір відрахувань до резервного фонду має бути не менше 5 відсотків від прибутку банку до досягнення ними 25 відсотків розміру регулятивного капіталу банку.

У разі коли діяльність банку може створювати загрозу інтересам вкладників та інших кредиторів банку, Національний банк України має право вимагати від банку збільшення розміру резервів щорічних відрахувань до них.

Банки зобов'язані формувати інші фонди та резерви на покриття збитків від активів відповідно до нормативно-правових актів Національного банку України» (ст. 36 Закону «Про банки і банківську діяльність») [4]. Банки повинні дотримуватися обов'язкових нормативів, встановлених відповідно до Законів України «Про банки і банківську діяльність та «Про Національний банк України» [4; 5].

3-поміж них можна назвати, наприклад, такі нормативи, як:

- мінімальний розмір статутного капіталу;

- нормативи достатності власних коштів;

- нормативи ліквідності кредитної організації;

- нормативи використання власних коштів банку для придбання акцій (часток) інших юридичних осіб.

Однак щодо страхових організацій таких жорстких (і виправдано жорстких) заходів не встановлено.

Водночас, окрім вимог щодо забезпечення фінансової надійності кредитної організації, одним із заходів, спрямованих на підвищення стійкості банківської системи України, є страхування банківських ризиків. Однак, як зазначають І. Мудь та О. Рудик: «В Україні страхування банківських ризиків є досить обмеженим, багато видів страхування, які масово використовуються в міжнародній практиці, майже не використовуються українськими банками, що пов'язано із специфічними умовами, які склалися в Україні. Також страховий ринок України ще недостатньо розви- нутий порівняно зі страховими ринками розвинутих країн, що спричинює ненадійність роботи українських страхових компаній.3 огляду на економічні умови в Україні, використання комплексного страхування ризиків банками дозволило 6 значно стабілізувати їх діяльність, захистити від широкого кола ризиків» [6].

Особливу увагу необхідно звернути на систему страхування банківських вкладів, основою для створення якої став Закон України від 23 лютого 2012 року № 4452-VI «Про систему гарантування вкладів фізичних осіб» [7].

Метою створення такої системи гарантування вкладів фізичних осіб стала потреба у захисті прав і законних інтересів вкладників банків, зміцнення довіри до банківської системи України, стимулювання залучення коштів у банківську систему України, забезпечення ефективної процедури виведення неплатоспроможних банків з ринку та ліквідації банків» [7].

Система страхування вкладів спрямована на скорочення ризиків настання несприятливих наслідків для вкладників у випадку невиконання банками своїх зобов'язань. Якщо у банку відкликана ліцензія на здійснення банківських операцій або Національний банк України ввів мораторій на задоволення вимог кредиторів такого банку, вкладник має право звернутися у Фонд гарантування вкладів фізичних осіб за відшкодуванням за своїм вкладом [8].

Положенням про порядок відшкодування Фондом гарантування вкладів фізичних осіб коштів за вкладами встановлено, що гарантована сума за рахунком - це умовна сума, що розраховується Фондом із загальної суми залишку коштів на рахунку та відсотків, зменшених на суму податку, та $є$ частиною гарантованої суми відшкодування коштів за вкладами одного вкладника в межах граничного розміру відшкодування коштів за вкладами станом на день початку процедури виведення Фондом банку з ринку, а у разі ліквідації банку з підстав, визначених частиною другою статті 77 Закону України «Про банки і банківську діяльність», - на день початку ліквідації банку [8]

Натомість, Фонд гарантує кожному вкладнику банку відшкодування коштів за його 
вкладом. Фонд відшкодовує кошти в розмірі вкладу, включаючи відсотки, станом на день початку процедури виведення Фондом банку з ринку, але не більше суми граничного розміру відшкодування коштів за вкладами, встановленого на цей день, незалежно від кількості вкладів в одному банку. Сума граничного розміру відшкодування коштів за вкладами не може бути меншою 200000 гривень [8].

Однак, варто зауважити, що страхові компанії згідно з чинним законодавством у систему гарантування вкладів фізичних осіб в Україні не входять, хоча світовий досвід показує, що в процесі зміцнення системи страхування банківських вкладів, в умовах, коли вона функціонує на постійній і стабільній основі, виникає тенденція до розширення охоплення фінансових установ системою страхування вкладів. Спонукальними причинами для цього може бути зближення комерційних банків і інших установ за характером діяльності, створення загальних умов конкуренції для установ різних типів, захист максимально широких груп дрібних вкладників.

При дослідженні систем страхування вкладів можна зазначити, що практично у всіх країнах кредитна система значно складніша, ніж в Україні, та включає і різні види банків, і фінансові установи небанківського типу.

Натомість, Н. Бортник та С. Ссімов звертають увагу на те, що небанківські кредитні організації мають право здійснювати лише окремі види банківських операцій, у допустимих Національним банком поєднаннях. Поняття банківської операції законом не визначається, але вичерпний перелік наводиться в Законі України «Про банки і банківську діяльність» [9, с. 175-182].

В Україні установи небанківського типу, найважливішими з яких є страхові компанії, пенсійні, пайові та інвестиційні фонди, не включаються в систему створення страхування вкладів саме 3 тієї простої причини, що вони не залучають кошти населення (або підприємств) у такій формі, як вклади.

У той же час необхідно зауважити, що правова природа страхових внесків близька до природи банківських вкладів. I в першому, і в другому випадках маються на увазі грошові кошти. Цілі розміщення грошей у фінансових установах обох видів також подібні: це забезпечення збереження грошових коштів та отримання доходу, при цьому дохід за банківськими вкладами виражається, як правило, у вигляді відсотків, а за страховими внесками - у вигляді страхової премії, що робить цілі цих вкладень принципово різними. I ті, й інші грошові кошти приймаються тільки установами (банками та страховими компаніями), які мають відповідні ліцензії. Причому установи обох видів зобов'язані забезпечувати збереження переданих їм коштів і своєчасність виконання своїх зобов'язань перед вкладниками і страхувальниками. В обох випадках у вкладника виникає право вимоги до фінансової установи.

Обидва види компаній займаються інвестуванням не власних, а залучених коштів, тобто фактично ризикують не власним капіталом, а чужими грошовими коштами.

\section{Висновки}

Підсумовуючи викладене вище, можемо констатувати, що існує ціла низка передумов для включення страхових компаній до системи страхування внесків фізичних осіб. Причому для цього немає необхідності створювати окрему систему, учасниками якої були б страхові компанії та їхні клієнти.

Натомість, система страхування вкладів вимагає залучення значних фінансових ресурсів, які можна отримати у вигляді внесків не тільки їі учасників, а й держави.

\section{Аітература}

1. Див.: Сульженко Ю. Форми і способи захисту суб'єктивних цивільних прав і законних інтересів. Право Украӥни. 2005. № 12. С. 24-28.; Курило В. Державне ліцензування як правова підстава підприємницької діяльності з надання послуг щодо охорони власності та громадян. Юридична Украйна. 2004. № 2 С. 50-54; Ромовська 3.В. Українське цивільне право: Загальна частина. Академічний курс: підручник. К.: Атіка, 2005. 560 с.; Кучер В.О. Окремі способи захисту права власності: проблемні питання URL: http://radnuk.info/statti/230tsuv-pravo/15234-2011-01-22-01-43-59.html.

2. Аиченко I. О. Адміністративно-правові основи гарантування захисту законних інте- 


\section{Адміністративне право}

\section{АНОТАЦІЯ}

Стаття присвячена дослідженню адміністративно-правових механізмів реалізаиіи державної політики у сфері страхування. З'ясовано сутність страхової діяльності та особливості ï̈ здійснення. Проведено аналіз співвідношення страхової та банківсъкої діяльності. Підкреслено, щз страхова діяльність, будучи одним з видів підприємництва, є суспільним процесом, що охоплюеться державним регулюванням у силу своєї сочіальної значимості. При иьому мета державного регулювання страхової діяльності полягає в упорядкуванні изього виду підприємниитва, забезпечення стабільності ринку страхових послуг $i$ захисту інтересів споживачів изого виду послуг. Регулювання страхової діяльності 3 боку держави здійснюється в публічних інтересах і спрямовано на досягнення соціально корисних результатів, шо стимулюють прогресивний розвиток страхування в державі.

Державне регулювання суспільних відносин має будуватися з урахуванням інтересів $і$ всъого суспільства (тобто публічних інтересів), і приватних інтересів окремих індивідів. Насамперед, ие стосується економічних відносин, мета державного регулювання яких - задоволення державних (публічних) інтересів щодо забезпечення економічного розвитку держави та захист законних економічних прав та інтересів приватних осіб.

Ключові слова: страхова діяльність, банківсъка діяльність, гарантування вкладів ббізичних осіб, адміністративно-правове регулювання, адміністративно-правові механізми, адміністративно-правовий режим, державна політика.

ресів громадян України у сфері власності. $B i$ сник Національного університету «Һввівскка політехніка». 2016. Вип. 855. С. 271-278.

3. Талапина Э. В. Вопросы организации управления государственной собственностью. Журнал российского права. 2001. № 3. C. 72.

4. Про банки і банківську діяльність: Закон України від 7 грудня 2000 року № 2121III. Відомості Верховноӥ Ради України. 2001. № 5. Ст. 30 .

5. Про Національний банк України: Закон України від 20 травня 1999 року № 679XIV. Відомості Верховної Ради України. 1999.№ 29. Ст. 238.

\section{SUMMARY}

The article is devoted to the study of administrative and legal mechanisms of realization of the state policy in the sphere of insurance. The essence of insurance activity and the peculiarities of its implementation have been clarified. The analysis of the ratio of insurance and banking activities. It is emphasized that insurance activity, being one of the types of entrepreneurship, is a social process covered by state regulation due to its social significance. The purpose of state regulation of insurance activities is to streamline this type of business, ensure the stability of the insurance market and protect the interests of consumers of this type of service. Regulation of insurance activities by the state is carried out in the public interest and is aimed at achieving socially useful results that stimulate the progressive development of insurance in the state.

State regulation of public relations should be based on the interests of society as a whole (ie public interests) and the private interests of individuals. First of all, this applies to economic relations, the purpose of state regulation of which is to satisfy the state (public) interests in ensuring the economic development of the state and to protect the legitimate economic rights and interests of individuals.

Key words: insurance activity, banking activity, guarantee of deposits of individuals, administrative and legal regulation, administrative and legal mechanisms, administrative and legal regime, state policy.

6. Мудь I.В., Рудик О.Р. Страхування банківських ризиків в Україні. Стратегічні орієнтири. 2018. URL: http://libfor.com/index. php?newsid $=316$.

7. Про систему гарантування вкладів фізичних осіб: Закон України від 23 лютого 2012 року № 4452-VI. Відомості Верховної Ради України. 2012. № 50 Ст. 564.

8. Про затвердження Положення про порядок відшкодування Фондом гарантування вкладів фізичних осіб коштів за вкладами: Рішення виконавчої дирекції Фонду гарантування вкладів фізичних осіб від 09.08.2012 р. № 14. Обфічійний вісник Украӥни. 2012. № 72. Ст. 2912.

9. Бортник Н. П., Есімов С. С. Банківська діяльність як об'єкт адміністративно-правового регулювання. Наше право. 2019. № 1. C. $175-182$. 